\section{IODOFORM INJECTIONS IN PULMONARY TUBERCULOSIS.}

To the Editor of THE LANCET.

SIRS,-_I read with interest Dr. E. Curtin's letter in THE LANCET of April 12th. He either omits to mention or has not experienced those dangers and inconveniences to the patients resulting from this treatment, upon which stress has been laid by writers in both medical and lay papers. I venture to offer a few remarks bearing directly on this aspect of the subject.

During the past few months I have administered iodoform dissolved in ether, plus a small percentage of "paroleine," intravenously to 54 patients (32 men, 20 women, and 2 children) in different stages of pulmonary tuberculosis, the total number of injections being 1800 odd. If the technique be carefully and correctly observed the whole matter should be absolutely painless. The patient usually experiences a transient fit of coughing of from 10 to 20 seconds' duration.

In but one case in the series was the coughing excessive; this unpleasant, and in some cases possibly dangerous, symptom was obviated by only allowing the fluid to enter the blood stream minim by minim, with an appreciable interval between each drop. In two other cases slight hæmorrhages certainly occurred, but whether post hoc or propter hoo it was quite impossible to ascertain; when the sputum became clear the injections were continued, and no return of the hæmorrhage took place. Up to the time of writing no patient has objected to the treatment on the grounds of personal discomfort.

I purposely refrain at present from drawing any conclusions as to therapeutic value, only a limited number of patients having completed the treatment.

I am, Sir, yours faithfully,

Frank Crosbie, M.D. Dub. Univ.

The Hospital, Newcastle, co. Wicklow, April 14th, 1913.

\section{TUBERCULOSIS OFFICERS, SCHOOL MEDICAL OFFICERS, AND THE MEDICAL OFFICERS OF HEALTH (SUPERANNUATION BILL). \\ To the Editor of THE LANCET.}

SiR,-I should like to thank Dr. Alexander Graham for his timely letter in THE LANCET of April 12th, and to support his appeal for the urgent need of an amendment to the Medical Officers of Health (Superannuation) Bill, so that under "medical officers of health" school medical officers and tuberculosis officers will be included as well. I wish to specially urge the inclusion of tuberculosis officers for the following reasons:-

1. They are whole-time medical officers, and as such are unable to augment their income by doing other work. A part-time medical officer of health is included in the Bill. He usually has a large and lucrative general practice, and is in a better financial position than the tuberculosis officer.

2. Better men will undoubtedly apply for these posts if there is an assured superannuation scheme attached to them. The advantage to the community is obvious.

3. If medical officers of health are singled out for the superannuation scheme and tuberculosis officers excluded, the latter will feel under a grievance which cannot favourably affect the harmonious relations between them which are necessary in the public interest.

4. It should be easy and practical to include tuberculosis officers because all these appointments are quite new, and, therefore, payments can be made in every case from the commencement of the appointment.

I trust every tuberculosis officer will support Dr. Graham in this important matter by writing to him as he suggests. I am, Sir, yours faithfully,

\section{G. LIssant Cox}

Tubereulosis Officer for the County Palatine of Lancaster.

County Offices Preston-A pril 1 1 th, 1913:

\section{THE INDIVIDUAL TREATMENT OF DIABETES.}

To the Editor of THE LANCET.

SIR,-The celebrated exclamation, "Vous êtes orfèvre, Monsieur Josse," from $L^{\prime}$ Amour Médecin, came to my lips after reading Dr. Arany's able paper on "The Individual Treatment of Diabetes." 1 When he writes that our duty is to accommodate our treatment to each individual case, I feel sorry for the poor opinion he seems to have of the preArany era penny-in-the-slot treatment we must have evidently indulged in. But when he concludes that as regards dietary conditions the Austrian spas are "quite reliable" (parbleu!), that the German ones are " not quite so good," and that in the French resort "the patient is almost left at large," I really feel I cannot let such a drastice statement pass unchallenged.

If Dr. Arany had taken the trouble to come to Vichy and see for himself-as so many British doctors do to whos evidence $\mathrm{I}$ appeal-he would know that for several years the diet question has been settled in all leading Vichy hotels, to say nothing of the specialised maisons de régime. In every one of these places he will find a special cuisine for cases of diabetes and another one for cases of gastrohepatic disorders. Our patients are individually directed as regards their diet, and if the system is not "quite reliable," I would feel grateful to Dr. Arany if he kindly pointed ou the fault. Or are we to admit that our patients are at large while we French doctors are mentally "au maillot," and that, to reverse the balance, Carlsbad patients are stringently "caporalisés," while their doctors, as seems to me, are ato large? I am, Sir, yours faithfully,

Gustave MonoD,

M.D. Paris, L.R.C.P. Lond., M.R.C.S. Eng.

Vichy, Afril 6th, 1913.

\section{YEARS OF CONTRACT SERVICE.}

To the Editor of THE LANCET.

SIR,-The position of "parish doctor" may not be a very lofty one in our profession, and is not thought much of either by some practitioners or by the British public. The title is unfortunate and the pay is small. But the office is an honourable one and important to the health of the general community, for complaints are apt to be caught from the pauper. even by the rich and mighty in the land.

In 1871 I succeeded Mr. B. Hands as parish doctor of Hornsey, where he had been the sole medical resident for 47 years. He was a contemporary of my own father at St. Bart.'s Hospital, both being apprentioed to John Abernethy. Now, retiring after 42 years' service, I am fortunate enough to be able to say that I have not had a single official complaint as to my treatment of the poor. My salary has remained the same throughout, though the population of the district has increased from below 20,000 to about 90,000. On the whole I have enjoyed the position, more especially the post of public vaccinator, in which $I$ have preached the common sense of the procedure, while I can honestly say that $I$ have never seen any ill-effects from it.-I am, Sir, yours faithfully,

F. ORTON,

Surgeon-Lieutenant-Colonel, V.D. (retireō)

Crouch End, Hornsey, N., April 6th, 1913.

*** We congratulate our correspondent and the authority with whom he has worked apon this long and usefut record.-ED.L.

\section{THE POSITION OF ASSISTANT MEDICAL OFFICERS IN ASYLUMS.}

To the Editor of THE LANCET.

SrR,-I have read with some interest and considerabls astonishment the letter of your correspondent "Reform" in ThE LANCET of April 12th. The assertions he makes regarding the position and work of assistant medical officers in asylums appear to be much too sweeping. These conditions may exist in some asylums, but they certainly do not in all. My asylum experience extends over 20 years, and in no 